\title{
Does it Pay to Fulfill the Maastricht Convergence Criteria? \\ - Reflections on the Public Debt and Growth Nexus for selected European Economies
}

Bettina Bökemeier

Christiane Clemens 


\title{
Does it Pay to Fulfill the Maastricht Convergence Criteria? - Reflections on the Public Debt and Growth Nexus for selected European Economies
}

\author{
Bettina Bökemeier* and Christiane Clemens*
}

October 2016

\begin{abstract}
This paper empirically studies whether it pays off (in terms of economic growth) to fulfill the convergence criteria on the public budget and participation in the Eurozone. The analysis is based on data of European economies with a special focus on twelve Euro-zone members and a control group of six non-Euro countries for the years from 1970 to 2014. The results show that growth is higher if the debt to GDP ratio is below $60 \%$ compared to values above it. Moreover, a comparison with European economies outside the Euro-zone shows higher growth values for Euro-members than for the control group. Regression estimations reveal a negative relationship between the two variables for the Euro-group. For the control group the relationship is not statistically significant.
\end{abstract}

JEL: O4, H63, E62,

Keywords: Economic Growth, Fiscal Policy, Debt, European Union

*Department of Business Administration and Economics, Bielefeld University, P.O. Box 100131, 33501 Bielefeld, Germany. Corresponding author: Bettina Bökemeier, Phone: (+49) 521106 4858, E-mail: bboekemeier@wiwi.uni-bielefeld.de. We thank Florian Kock for data research. 


\section{Introduction}

With signing of the Treaty on the European Union (Maastricht Treaty) in 1992 several independent European countries joined together and formed the European Union (EU). By now, the EU has twenty eight member states and still it is promise and aspiration for many other states, for instance in south eastern Europe. Moreover, nineteen members agreed upon an even more narrow economic coordination by unifying monetary policy and introducing the common currency of the Euro.

The Maastricht Treaty (MT) and the Stability and Growth Pact require sound fiscal policies. For instance, Article 121 of European Union (1997)'s Consolidated Version of the Treaty on European Union calls for realization of "the sustainability of the government financial position". More precisely, in Article 1 of the protocol on the excessive deficit procedure of the MT defines the reference values of the public debt to GDP ratio at $60 \%$ and the budget deficit at $3 \%$ relative to GDP. But, the situation of the EU and its future is a highly discussed topic these days. Many urgent political, social and economic topics such as proceeding of European integration, structural problems and the current economic situation are concerning the society. Unemployment, the aging population and migration triggered by civil wars in the immediate neighborhood of the EU challenges social security budgets. Moreover, with the debate of United Kingdom's referendum and their decision in favor of an exit of the EU, the discussion on the future of the EU goes beyond the scientific community and concerns all EU citizens.

With this paper we reflect on the economics of the EU and the public finance situation. Especially, we analyze whether a membership pays off in terms of economic growth. We focus on the convergence criteria of the MT, which request a public debt ratio which should not exceed $60 \%$ of GDP and a budget deficit $3 \%$ of GDP (or below), where we put the special emphasize on the debt ratio level. Do sustainable fiscal policies induce or lead to higher economic growth? Is there a difference among European countries? Particularly, is it possible to detect a difference among EU members and non-EU members, or more precisely: does Euro-zone membership matter?

Our empirical analysis is based on the twelve core Euro-zone members: Austria, Belgium, Finland, France, Germany, Greece, Ireland, Italy, Luxembourg, The Netherlands, Portugal and Spain. Moreover, we compare their results with a control group of six European economies which consists of Denmark, Sweden and the United Kingdom (currently 
EU members) and Iceland, Norway and Switzerland. All of the latter have their own currency and do not take part in the Euro-zone. The times series cover annual observations from 1970 to 2014. It shows, that economic growth is higher in Euro-countries than in the control group of non-Euro economies. Moreover, it pays off to fulfill the budget reference values: GDP growth is higher if the debt ratio is below $60 \%$. This holds true independent of the common currency or EU-membership.

Regarding literature contributions, there are many empirical papers analyzing the relationship between public finances and economic growth. A starting point may be the contribution by Reinhart and Rogoff (2010), who study the influence of public debt on economic growth and find a threshold of $90 \%$ beyond which that relationship turns negative. Though their analysis has been criticized, there are many other studies also indicating a negative relationship between debt and growth such as Kumar and Woo (2010), Checherita and Rother (2010) or Dreger and Reimers (2013) for instance. The latter two especially focus on European economies taking part in the Euro-zone. Plus, Dreger and Reimers (2013) study the effect for Euro-zone and non-Euro-zone members and distinguish sustainable and non-sustainable situations referring to the relationship between the primary surplus, the debt ratio and economic growth. Their central finding shows that the negative impact of the debt ratio holds only for the Euro-zone (independent of sustainability) whereas the negative effect diminishes in the broader panel of economies. They come to the conclusion that being monetary union member might involve an additional risk. Our paper goes into a similar direction, however, we focus on comparing growth rates separated by the debt ratio criteria based on the Maastricht benchmark. Plus, our data set is more extensive, both, regarding the time period (45 years) and the range of control countries. Our descriptive statistic results go into the opposite direction: growth rates are higher in the Euro-zone than in the control group of non-Euro economies. Plus, economic growth is higher if the debt ratios are kept low, i.e. below $60 \%$ of GDP. However, our regression outcome also shows a statistically significant effect for the Euro-members only.

The remainder is structured as follows, the next section presents the empirical part and describes the data set, the calculations and estimation results. Subsection 2.1 explains the basic information on the data series and sources and presents some graphical impressions of the central series. Subsection 2.2 presents the outcomes of statistical calculations and 
subsection 2.3 shows the results of a simple regression estimation and presents the results of the analyses and some robustness checks. Finally, section 3 summarized the central findings and concludes.

\section{Empirics}

\subsection{Data}

The selection of data was based on availability and the idea was to resort to as few sources as possible in order to minimize biases based on combining different sources. We tried to get (or construct) consistent and reliable data series to set up a balanced data panel for the calculations. The main sources are OECD (2016) for the growth rate and AMECO (2016) for the debt ratio. Missing values of the debt ratio haven been supplemented by Abbas et al. (2010) data set and Statistics Norway (2016, 1981 \& 1982 observation). Economic growth is captured in real terms, measured as GDP volume annual growth rate in percent. The base year is 2010. The 1970 growth rate for Luxembourg is taken from World Bank (2016) World Development Indicators. Luxembourg's budget balance data for 1990-1994 stems from SVR (Sachverständigenrat zur Begutachtung der gesamtwirtschaftlichen Lage 2015). For most countries inflation data is taken from the World Bank (2016) World Development Indicators, measured by the consumer price index. However, due to data availability, for Germany it comes from International Monetary Fund (2013, updated by International Monetary Fund, 2014) and is based on calculations of changes in GDP deflator. The series have been tied together in 1992 due to reunification. For the UK, inflation also is based on the GDP deflator (source: World Bank, 2016). Icelandic data has been supplemented by Central Bank of Iceland (1999). Iceland's 1980 public debt observations has been taken from International Monetary Fund (2016).

The following graphics illustrate the central series of annual real GDP growth and debt ratios for the selection of countries. The lines present a non-parametric loess smooth. ${ }^{1}$ Figures 1(a) and 1(b) show them for the Euro-zone economies. Figures 1(c) and 1(d) present growth and debt for the control group of non-Euro economies. It shows that for the Euro-group the growth and debt pattern was not uniform among countries, however,

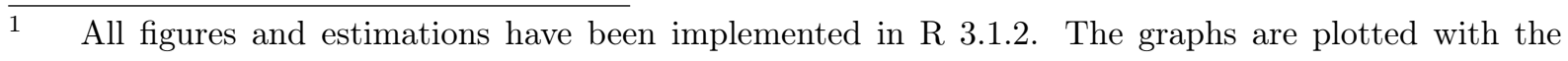
command 'scatterplot' in package car, see ? for details. 


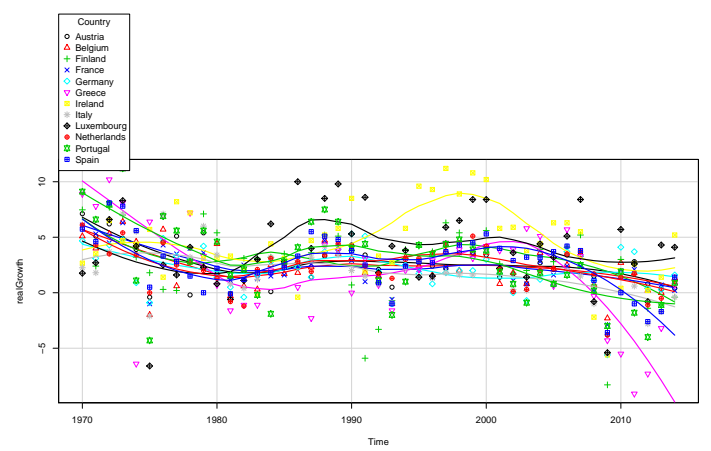

(a) Annual growth rate, Euro-12

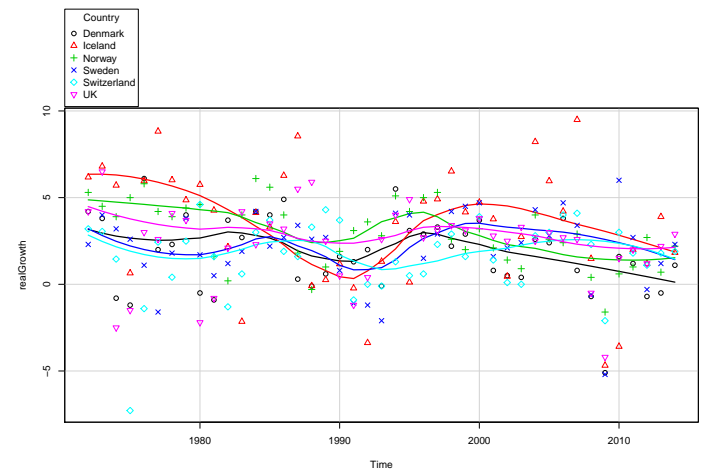

(c) Annual growth rate, Non-Euro

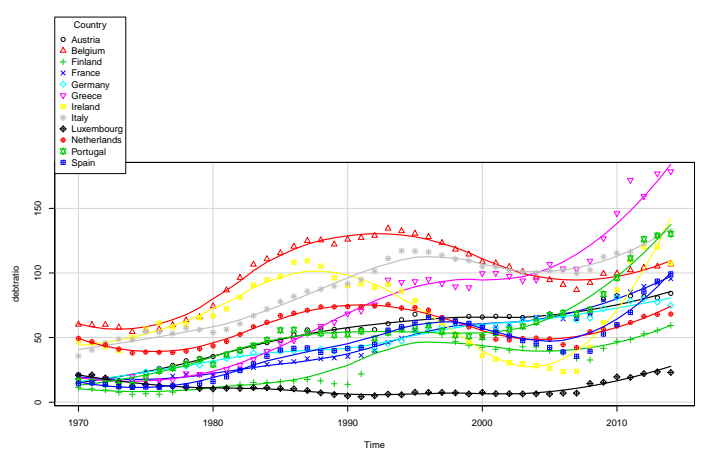

(b) Debt ratio, Euro-12

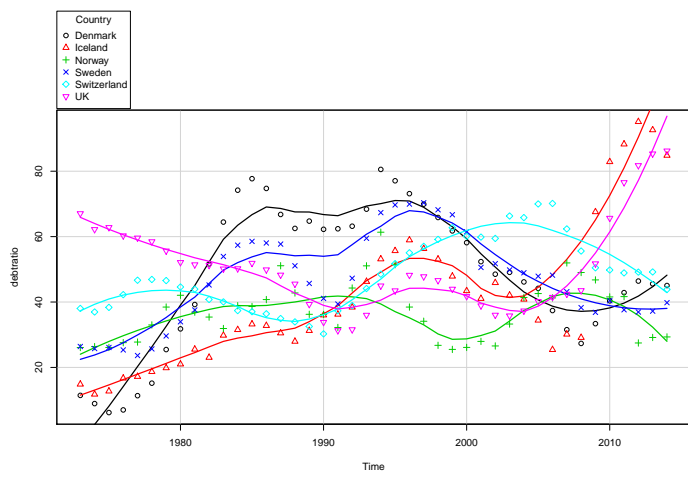

(d) Debt ratio, Non-Euro

Figure 1: EU Growth Rates and Debt Ratios

there seems to be mostly positive growth rates for the earlier years of the analysis, which turned negative with the crisis. Also, the debt ratios ran differently, but there is a general positive trend observable, especially with the time period after 2007. Also, in the control group there is a lot of variability in both series. Especially the development of the debt ratio differs among groups. Whereas Sweden and Denmark were able to bring down their ratios following an increase in the seventies and eighties, other countries like the Iceland experience a rather steady increase. Certainly, the crisis is visible in the recent years.

\subsection{Statistical calculations}

Table 1 presents the average real economic growth values of the 12 Euro countries under investigation. According to the reference value they are separated in observations with the debt ratio below $60 \%$ and higher than $60 \%$. The last column presents the overall average 
Table 1: Growth rate Euro-zone, separated by debt ratio level

\begin{tabular}{|c|c|c|c|c|}
\hline Country & Debt ratio $\leq 60 \%$ & Debt ratio $>60 \%$ & Average & Time period \\
\hline Austria & $3.09 \quad(\mathrm{~N}=23)$ & $1.82(\mathrm{~N}=22)$ & $2.47 \quad(\mathrm{~N}=45)$ & 1970-2014 \\
\hline Belgium & $3.47(\mathrm{~N}=7)$ & $2.00 \quad(\mathrm{~N}=38)$ & $2.23 \quad(\mathrm{~N}=45)$ & 1970-2014 \\
\hline Finland & $2.57 \quad(\mathrm{~N}=45)$ & - & $2.57 \quad(\mathrm{~N}=45)$ & $1970-2014$ \\
\hline France & $2.78 \quad(\mathrm{~N}=29)$ & $1.42(\mathrm{~N}=16)$ & $2.30 \quad(\mathrm{~N}=45)$ & $1970-2014$ \\
\hline Germany & $2.38 \quad(\mathrm{~N}=32)$ & $1.19(\mathrm{~N}=13)$ & $2.03(\mathrm{~N}=45)$ & $1970-2014$ \\
\hline Greece & $3.02 \quad(\mathrm{~N}=19)$ & $0.99 \quad(\mathrm{~N}=26)$ & $1.85(\mathrm{~N}=45)$ & 1970-2014 \\
\hline Ireland & $5.59 \quad(\mathrm{~N}=18)$ & $3.63 \quad(\mathrm{~N}=27)$ & $4.41 \quad(\mathrm{~N}=45)$ & $1970-2014$ \\
\hline Italy & $3.41 \quad(\mathrm{~N}=12)$ & $1.16 \quad(\mathrm{~N}=33)$ & $1.76 \quad(\mathrm{~N}=45)$ & $1970-2014$ \\
\hline Luxembourg & $3.65(\mathrm{~N}=45)$ & - & $3.65(\mathrm{~N}=45)$ & $1970-2014$ \\
\hline The Netherlands & $2.22 \quad(\mathrm{~N}=26)$ & $2.48 \quad(\mathrm{~N}=19)$ & $2.33 \quad(\mathrm{~N}=45)$ & $1970-2014$ \\
\hline Portugal & $3.51 \quad(\mathrm{~N}=34)$ & $-0.04 \quad(\mathrm{~N}=11)$ & $2.63 \quad(\mathrm{~N}=45)$ & $1970-2014$ \\
\hline Spain & $2.95 \quad(\mathrm{~N}=35)$ & $1.38(\mathrm{~N}=10)$ & $2.60 \quad(\mathrm{~N}=45)$ & 1970-2014 \\
\hline Panel & $3.11(\mathrm{~N}=325)$ & $1.75 \quad(\mathrm{~N}=215)$ & $2.57(\mathrm{~N}=540)$ & $1970-2014$ \\
\hline
\end{tabular}

in each country. The final row shows the pooled average of the panel. ${ }^{2}$ The number of observations is listed in parenthesis. There are $N=45$ observations per country leading to a total of 540 observations.

It shows that for all countries in the panel, the average growth rate is higher if the debt ratio is kept below the $60 \%$ reference value compared to situations when the debt ratio is higher (3.11\% growth versus $1.75 \%$ growth). This also holds true for all individual countries except the Netherlands. For the interpretation from the economic policy perspective this result supports the view that is does pay off to fulfill the Maastricht criteria.

Concerning causality, here we assume that debt exceeds an influence on growth. Certainly, we are aware that the effect may also go the other way around, i.e. economic growth may affect the debt situation. However, we are interested in this direction of impact.

In order to be able to evaluate and assess this outcome, we reiterate our calculations for a selection of six European countries, which either do not take part in the Euro-area $2 \quad$ All values in tables 1 and 2 refer to the geometrical mean. 
Table 2: Growth rates Non-Euro-Group, separated by debt ratio level

\begin{tabular}{c|c|c|c|c|c} 
Country & Debt ratio $\leq \mathbf{6 0 \%}$ & Debt ratio $>\mathbf{6 0 \%}$ & Average & Time period \\
\hline Denmark & $1.34(\mathrm{~N}=28)$ & $2.46(\mathrm{~N}=17)$ & $1.76(\mathrm{~N}=45)$ & $1970-2014$ \\
Sweden & $2.04(\mathrm{~N}=38)$ & $2.70(\mathrm{~N}=7)$ & $2.14(\mathrm{~N}=45)$ & $1970-2014$ \\
United Kingdom & $2.58(\mathrm{~N}=12)$ & $1.50(\mathrm{~N}=33)$ & $2.29(\mathrm{~N}=45)$ & $1970-2014$ \\
Iceland & $3.84(\mathrm{~N}=36)$ & $0.26(\mathrm{~N}=7)$ & $3.25 \quad(\mathrm{~N}=43)$ & $1972-2014$ \\
Norway & $2.97(\mathrm{~N}=44)$ & $2.80(\mathrm{~N}=1)$ & $2.97 \quad(\mathrm{~N}=45)$ & $1970-2014$ \\
Switzerland & $1.55(\mathrm{~N}=37)$ & $2.05(\mathrm{~N}=7)$ & $1.63 \quad(\mathrm{~N}=44)$ & $1971-2014$ \\
\hline Panel & $2.44(\mathrm{~N}=195)$ & $1.91(\mathrm{~N}=72)$ & $2.34(\mathrm{~N}=267)$ & $1972-2014$ \\
\hline
\end{tabular}

(and therefore are not bound by the Maastricht treaty) or are not part of the European Union. Table 2 presents the average growth rates separated by debt ratios below or above $60 \%$. Again, the last column presents the overall average in each country. The final row shows the pooled average of the panel. There are $N=45$ observations per country, except for Switzerland ( $\mathrm{N}=44$, no 1970 obs.) and Iceland ( $\mathrm{N}=43$, no 1970, 1971 obs.).

Regarding the growth-debt ratio nexus, the results from table 2 present a similar overall impression for the control group: economic growth is higher if the debt ratio is lower than $60 \%$. This outcome does not hold for each economy, for instance, the Danish, Swedish and Swiss growth rates are even higher if the debt ratio exceeds $60 \%$. However, for the other countries the outcome supports the results from the Euro-zone economies: growth is higher if debt is below the reference value.

Moreover, a comparison of table 1 and table 2 reveals another interesting result. It does not only pay off to fulfill the reference value, but it also pays to participate in the Euro-zone. On average the growth rate has been higher for the Euro-12 group (2.57\%) than for the control group $(2.34 \%)$ over the past 45 years. Of course, the idea of the EU/Euro-zone came up later and became more tangible during the 1990s, nevertheless these long-run data suggest that it may pay off to participate.

Certainly, as regards the distribution or the amount of observations in each category, the panel is characterized by heterogeneity. The numbers differ, not only on country level, but also on the aggregated level. About $60 \%$ of the total observations are in the category of $60 \%$ and lower, while about $40 \%$ are ascribed to values above the benchmark in the 
Euro-zone. Of course, this may be due to influences of countries which do not have debt ratios above $60 \%$ such as Luxembourg or Finland. But it should also be kept in mind that there are economies in which in a majority of periods the debt ratio was higher than $60 \%$, such as Belgium or Italy. This also holds for the control group of non-Euro economies. For the whole group over $70 \%$ of the observations reveal a debt ratio below $60 \%$ of GDP. However, the example of the United Kingdom shows, that most of the time the debt ratio was above the benchmark.

Nevertheless, the central massage remains, if debt ratios are kept low, it pays off in terms of higher growth rates. Plus, Euro-zone members on average exceed higher economic growth than non-members.

\subsection{Estimation results}

This section elaborates a little more on the relationship between economic growth and the public debt ratio in the selected countries. We estimate the following regression given by equation (1) (cf. for instance Kumar and Woo (2010) or Fincke and Greiner (2015)):

$$
\gamma_{i, t}=a_{0}+\sum_{j} a_{j} Z_{j, i, t-1}+\epsilon_{i, t}
$$

Here, $\gamma_{i, t}$ indicates the real GDP growth rate, $i$ reflects the country and $t$ states time. $Z$ is a vector of regressors, $\epsilon$ is the error term. All regressor variables enter the regression in lagged terms. In this way it is possible to measure the effect of a certain variable on subsequent output growth (and it is more plausible that the reaction takes some time to adjust and rather does not effect growth immediately). Due to this lagged structure, the model covers only the years from 1971 to $2014 .^{3}$ The variable of interest is the public debt ratio, which is included in $Z$. The other regressors are standard macroeconomic variables. Especially we included inflation, the current account balance and government consumption as controls.

The results for the Euro-zone are presented in table 3. It shows that all of the coefficients are statistically significant. Not only the debt ratio but also the controls provide an important contribution in explaining economic growth in the selected economies.

The findings present a negative correlation between the debt ratio in the previous period and the subsequent economic growth in the group of the twelve Euro-zone economies.

3 Technically, this also mitigates endogeneity. 
Table 3: Regression results Euro-zone

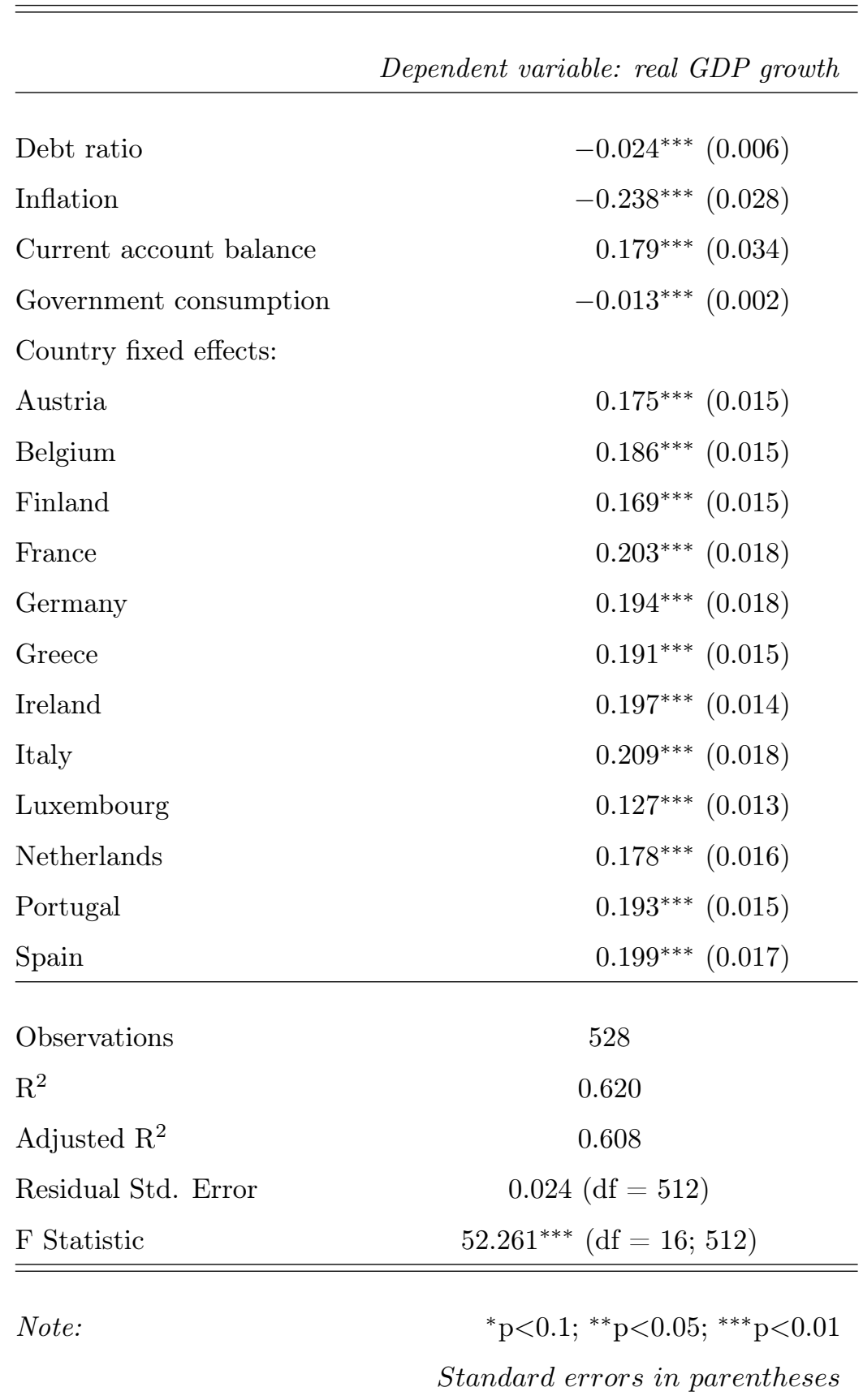

Moreover, the controls show the expected signs: inflation has a negative influence on growth, just like government spending. However, the current account balance indicates to have a positive effect on subsequent economic growth. These outcomes are in line with most of the literature: there seems to be a negative relationship between public debt and economic growth (e.g. Kumar and Woo (2010)). From the economic policy perspective 
Table 4: Regression results control group

\begin{tabular}{lcc}
\hline \hline & & \\
& Dependent variable: real GDP growth \\
\hline Debt ratio & -0.002 & $(0.010)$ \\
Inflation & -0.022 & $(0.019)$ \\
Current account balance & $0.061 \quad(0.038)$ \\
Government consumption & $-0.006^{*}(0.003)$ \\
Country fixed effects: & \\
Denmark & $0.083^{* *}(0.027)$ \\
Iceland & $0.059^{* * *}(0.012)$ \\
Norway & $0.091^{* * *}(0.025)$ \\
Sweden & $0.089^{* *}(0.028)$ \\
Switzerland & $0.076^{* *}(0.025)$ \\
UK & $0.101^{* *}(0.032)$ \\
\hline Observations & 252 \\
$\mathrm{R}^{2}$ & 0.517 \\
Adjusted $\mathrm{R}^{2}$ & 0.497 \\
Residual Std. Error & ${ }^{*} \mathrm{p}<0.1 ;{ }^{* *} \mathrm{p}<0.05 ;{ }^{* * *} \mathrm{p}<0.01$ \\
F Statistic & Standard errors in parentheses \\
\hline \hline &
\end{tabular}

this can be interpreted in a way that for Euro-zone economies it is especially important to keep debt ratios low in order to keep up economic growth.

This regression analysis is also conducted for the control group of non-Euro economies. Table 4 presents the outcomes. ${ }^{4}$ In table 4 all coefficients show the expected signs, but only the regressor government consumption is statistically significant (besides the country fixed effects). Thus, the findings for the control group signify that the negative effect of debt on growth is not as distinct as for the Euro-group above. For the debt growth relationship this can be interpreted in a way that for non Euro-zone economies this correlation is not as pronounced as for the members, however, the statistical calculations from table 2

$4 \quad$ Please note, due to missing observations this data set runs only from 1973-2014 with lagged regressors. 
Table 5: Results robustness check: plain model

\begin{tabular}{ccc}
\hline \hline $\begin{array}{c}\text { Estimation } \\
\text { Country: }\end{array}$ & $\begin{array}{c}\gamma_{t} \sim b_{t-1} \\
\text { EU group }\end{array}$ & $\begin{array}{c}\text { Dependent variable: real GDP growth } \\
\text { Control group }\end{array}$ \\
\hline \hline Debt ratio & $-0.021^{* * *}(0.004)$ & $-0.011 \quad(0.009)$ \\
\hline \hline Note: & & ${ }^{*} \mathrm{p}<0.1 ;{ }^{* *} \mathrm{p}<0.05 ;{ }^{* * *} \mathrm{p}<0.01$ \\
& & Standard errors in parentheses
\end{tabular}

indicate that the economic growth rates are higher if debt ratios are kept low for these non-Euro countries, too.

In order to check how robust our results are we conducted some robustness checks with the central focus on the debt-growth relationship. First, we checked on the plain relationship of the lagged debt ratio $b_{t-1}$ on growth $\gamma_{t}$ (no control variables) in a simple pooled OLS model. The outcome is presented in table 5. The results confirm the findings from above: the coefficient is negative for both, the EU group and the control group, but only statistically for the former.

If we now take into consideration that this panel spans over four decades and during these years many political and economic changes happened on the continent, a natural idea would be to separate the effects over time. Instead of a formal structural break test, we split the regressions into the four decades ${ }^{5}$ and present the estimation outcomes separately. We pool the observations of each group to present the common response for EU members and countries outside. Table 6 presents the results.

It shows that for the EU group the response only becomes significant for the last two decades, i.e. after 1993. This supports the view that with the intensified European integration many things changed for these countries. This effect is not visible for the economies outside the Union. The plots for the estimations are visualized in figures $2 \mathrm{a}$ and $2 \mathrm{~b}$. Certainly, the goodness of fit is improvable, but the plots nicely depict the rather loose relation in the 70 s and 80 s for the $\mathrm{EU}$ then becoming negative with the latter

5 Technically speaking, we divide the time period into four equally spaced, non-overlapping intervals, i.e. 1971-1981, 1982-1992, 1993-2003, 2004-2014. Each one consists of 11 years. Please note, due to the shorter time period available, for the control group the first interval starts in 1973. 
Table 6: Results robustness check: plain model by decades

\begin{tabular}{cccc}
\hline \hline $\begin{array}{c}\text { Estimation: } \\
\text { Country: }\end{array}$ & $\begin{array}{c}\gamma_{t} \sim b_{t-1} \\
\text { EU group }\end{array}$ & $\begin{array}{c}\text { Dependent variable: real GDP growth } \\
\text { Control group }\end{array}$ \\
\hline \hline Debt ratio & & & \\
$1970 \mathrm{~s}$ & 0.006 & $(0.015)$ & $-0.050^{* *}(0.025)$ \\
$1980 \mathrm{~s}$ & -0.003 & $(0.007)$ & $0.021 \quad(0.022)$ \\
$1990 \mathrm{~s}$ & $-0.012^{*}$ & $(0.007)$ & $0.006 \quad(0.016)$ \\
$2000 \mathrm{~s}$ & $-0.031^{* * *}(0.007)$ & $-0.009 \quad(0.019)$ \\
\hline \hline Note: & & & ${ }^{*} \mathrm{p}<0.1 ;{ }^{* *} \mathrm{p}<0.05 ;{ }^{* * *} \mathrm{p}<0.01$ \\
& & & Standard errors in parentheses
\end{tabular}

two periods. For the selected economies outside the EU, the relationship only shows a significant relationship in the 70 s.

Moreover, the main message remains: high growth goes along with low debt ratios. This was the case for the EU members in the early phase of the intervals (especially the 1970s). Moreover, the binding regulations for sustainable public finances in terms of low deficits $(<3 \%$ of GDP) and low debt ratios $(<60 \%$ of GDP) as they are written in the MT can be justified, as the EU group seems to have more difficulties to meet them especially in recent years, which then may help to explain the negative correlation in table 6 .

\section{Conclusion}

This paper analyses the relationship between public debt and economic growth for selected European economies empirically. They are divided into two groups, the EU 12, which all have the Euro as common currency and the control group which consists of six economies that are non Euro-members and some even not EU members. In a first step, for each group the economic growth rates are studied by separating the debt ratio in values below $60 \%$ of GDP and above. It shows that if debt ratios are kept below the Maastricht benchmark, growth rates are higher. This holds true for both groups. Moreover, it shows, that growth rates are higher in the Euro-zone than in the control group. From an economic policy perspective this can be interpreted that it does pay of to be a Euro-zone member. Even if the tight coordination may come along with some difficulties. 
This latter aspect becomes clear in the second part of the analysis. The regression estimations yields a negative effect of increasing public debt on subsequent growth. This is statistically significant for the Euro-zone group, while the coefficient is not significant for the countries of the control group. Obviously it is especially important to run low debt ratios for Euro-members with their tight interrelations and dependencies. Separating the response by decades for both groups supports this view. It shows that this negative effect becomes especially pronounced since 1993 for the EU members. This impact is not visible for the economies outside the Union.

Regarding policy implications the results call for prudent fiscal decisions especially in the Euro-zone. They seem to be more prone to the negative relationship between public debt and growth. For keeping up growth and prospects for the future these aspects should be kept in mind in order to hold and maintain the result that growth is higher inside the Euro-zone.

\section{References}

Abbas, S., N. Belhocine, A. A. ElGanainy, and M. Horton (2010). A historical public debt database. IMF Working Papers, 1-26, last data access: May 20th 2016.

AMECO (2016). AMECO, AMECO Database, http://ec.europa.eu/economy_ finance/ameco/user/serie/SelectSerie.cfm, last access: May 31st, 2016.

Central Bank of Iceland (1999). Monetary Bulletin, A quartely Publication of the Central Bank of Iceland, Tables and Charts, Historical economic indicators, http://www.cb.is/publications/publications/publication/1999/11/ 01/November-1999/, last access: June 16th, 2016. Vol. 1, no. 1, November.

Checherita, C. and P. Rother (2010). The impact of high and growing debt on economic growth. an empirical investigation for the euro area. ECB working paper series number 1237.

Dreger, C. and H.-E. Reimers (2013). Does euro area membership affect the relation between gdp growth and public debt? Journal of Macroeconomics 38, 481-486.

European Union (1997). Consolidated Version of the Treaty on European Union (English ed.). Official Journal of the European Communities, C 340, 10. November 1997, access 
via: http://eur-lex.europa.eu/en/treaties/index.htm html version, last access June 1st, 2011.

Fincke, B. and A. Greiner (2015). Public debt and economic growth in emerging market economies. South African Journal of Economics 83(3), 357-370.

International Monetary Fund (2013). International Statistical Yearbook, IMF's International Financial Statistics. via StatistikNetz.de, DSI Data Service 8 Information.

International Monetary Fund (2014). World Economic Outlook database, October 2014, http://www.imf .org/external/pubs/ft/weo/2014/02/weodata/index.aspx, last access: February 23rd, 2015.

International Monetary Fund (2016). IMF eLibrary data, Historical Public Debt database, http : //data.imf .org/?sk=806ED027-520D-497F-9052-63EC199F5E63\&ss= 1441803350568, last access: June 16th, 2016.

Kumar, M. S. and J. Woo (2010). Public debt and growth. IMF Working Paper $W P / 10 / 174$.

OECD (2016). OECD.Stat, OECD National Accounts Database, http://stats.oecd. org/index . aspx?DatasetCode=SNA_TABLE1, last access: May 31st, 2016.

Reinhart, C. and K. Rogoff (2010). Growth in a time of debt. American Economic Review $100(2)$, 573-8.

Statistics Norway (2016). Public Sector database, https://www.ssb.no/en/, last access: May 27st, 2016.

SVR (2015). Statistics, International Time Series, Schluesselindikatoren der Wirtschaft, ZR10, Access via: http://www.sachverstaendigenrat-wirtschaft.de/fileadmin/ dateiablage/download/gutachten/03_ges .pdf, as of OKT 1st, 2015, last access June 15 th, 2016.

World Bank (2016). World Development Indicators, last access: June 16th 2016. 

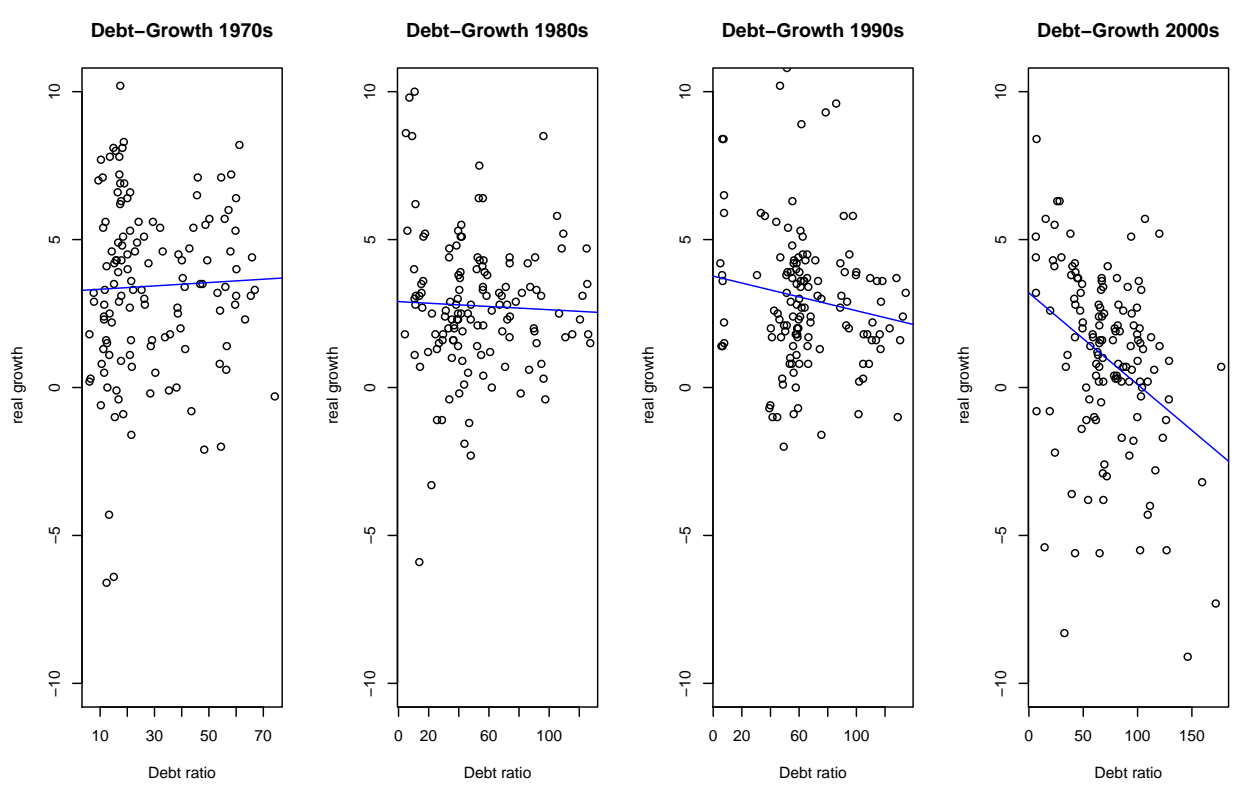

(a) Plots by decades, Euro-12

\section{Debt-Growth 1970s}

Debt-Growth 1980s

Debt-Growth 1990s

Debt-Growth 2000s
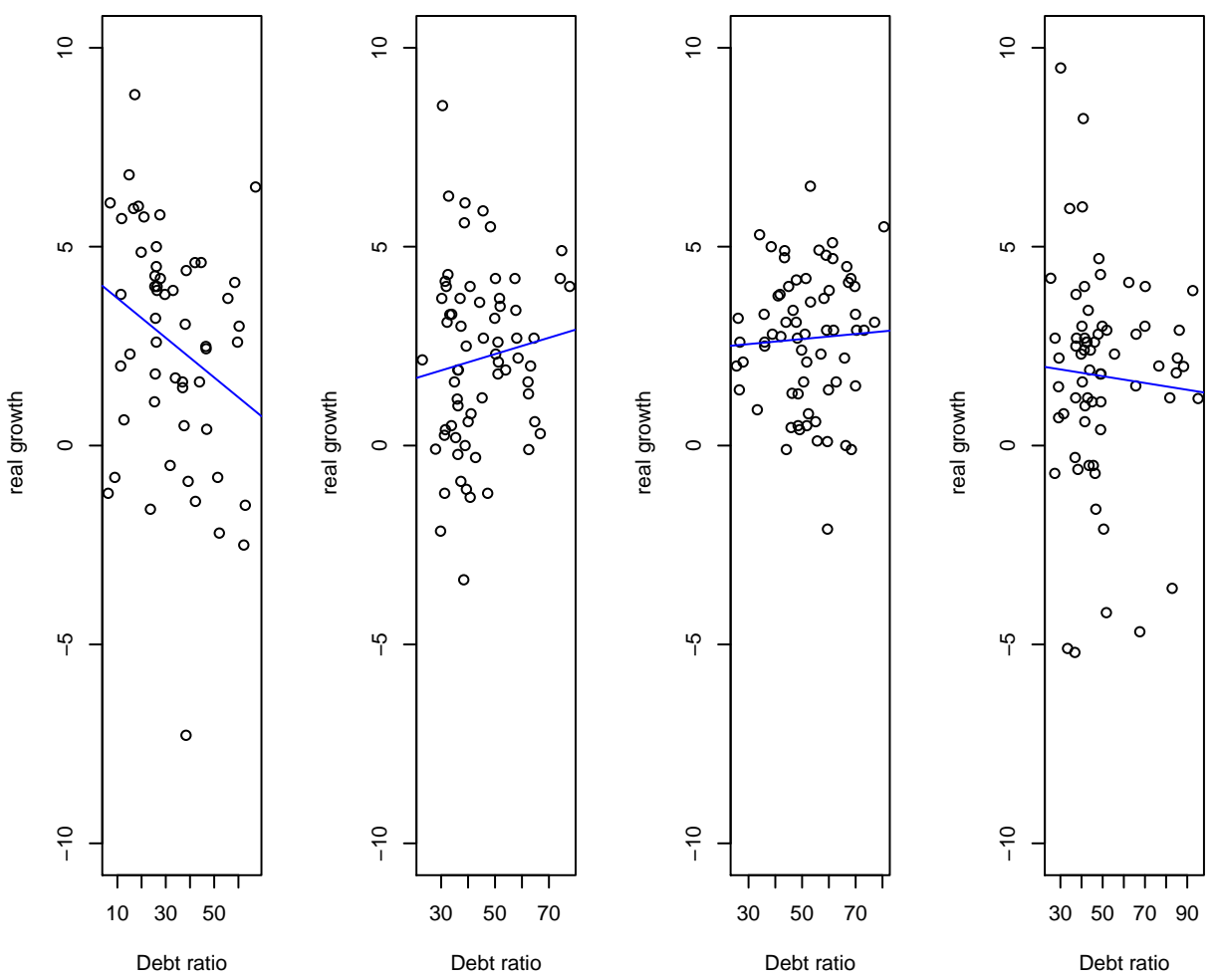

(b) Plots by decades, Non-Euro

Figure 2: Plots separated by decades 